\title{
Motivational Profiles in High School Students: Generation and Use of Volitional Strategies
}

\author{
María del Socorro Rodríguez-Guardado ${ }^{1}$ \\ Martha Letícia Gaeta ${ }^{1}$
}

\begin{abstract}
This research had as its main purpose to analyze the generation and use of volitional strategies - motivational and emotional control -, based on the motivational profile of the students, through a mixed methodology. Two standardized instruments (CMA and AVSI) were applied to 204 Mexican high school students, between 16 and 18, to identify their motivational profile. Semi-structured interviews were carried out to understand how they generate the volitional strategies they use. Results show that most students adopted a profile oriented to multiple goals, characterized by more volitional strategies use. They also stated that they used volitional strategies to concentrate on studying and have time to perform other tasks. It is considered necessary to design programs that promote volitional strategies, strengthening the commitment and sustained effort required to achieve academic goals in high school.
\end{abstract}

Keywords: motivation, emotions, students, educational objectives

\section{Perfis Motivacionais em Estudantes do Ensino Médio: Geração e Uso de Estratégias Volitivas}

\begin{abstract}
Resumo: Este estudo teve por objetivo analisar a geração e o uso de estratégias volitivas - controle motivacional e emocional -, com base no perfil motivacional dos alunos, utilizando uma metodologia mista. Dois instrumentos padronizados (CMA y AVSI) foram aplicados em 204 estudantes mexicanos do ensino médio, entre 16 e 18 anos, a fim de identificar seu perfil motivacional e o uso de estratégias volitivas. Foram realizadas entrevistas semiestruturadas para entender como geram as estratégias volitivas por eles utilizadas. Os resultados mostram que a maioria dos alunos adotou um perfil orientado para objetivos múltiplos, caracterizado por uma maior utilização de estratégias volitivas. Eles também afirmaram que usavam estratégias volitivas principalmente para se concentrar no estudo e ter tempo para realizar outras tarefas. Considera-se necessário desenhar programas que promovam estratégias volitivas e que fortaleçam o comprometimento e esforço sustentado, condições necessárias para atingir os objetivos acadêmicos no ensino médio.
\end{abstract}

Palavras-chave: motivação, emoções, estudantes, objetivos educacionais

\section{Perfiles Motivacionales en Estudiantes de Bachillerato: Generación y Uso de Estrategias Volitivas}

\begin{abstract}
Resumen: Este estudio tuvo como propósito principal analizar la generación y uso de estrategias volitivas - de control motivacional y emocional -, en función del perfil motivacional de los estudiantes, mediante una metodología mixta. Se aplicaron dos instrumentos estandarizados (CMA y AVSI) a 204 estudiantes de Bachillerato mexicanos, entre 16 y 18 años, para identificar su perfil motivacional. Asimismo, se realizaron entrevistas semi-estructuradas para comprender cómo generan las estrategias volitivas que utilizan. Los resultados muestran que los alumnos en su mayoría adoptaron un perfil orientado a metas múltiples, caracterizado por un mayor uso de estrategias volitivas. Además, manifestaron usar estrategias volitivas principalmente para concentrarse en el estudio y tener tiempo para realizar otras tareas. Se considera necesario diseñar programas que promuevan el uso de estrategias volitivas, que fortalezcan el compromiso y esfuerzo sostenido necesarios para el logro de las metas académicas en el bachillerato.
\end{abstract}

Palabras clave: motivación, emociones, estudiantes, objetivos educacionales

\footnotetext{
${ }^{1}$ Universidad Popular Autónoma del Estado de Puebla, Puebla, México
} Correspondence address: Martha Leticia Gaeta. Universidad Popular Autónoma del Estado de Puebla, Facultad de Educación. 21 Sur 1103 Colonia Santiago Puebla, Puebla 72410, México. E-mail: marthaleticia.gaeta@upaep.mx
One of the main goals of education is for students to be autonomous in their learning process, to participate and to motivate themselves. In this sense, self-regulation 
of learning has become a central topic for research, generating valuable contributions to educational practice. Models on self-regulated learning consider these students to be autonomous, thoughtful, efficient and have cognitive and metacognitive skills, such as motivational beliefs and attitudes necessary for their learning (Panadero \& AlonsoTapia, 2014; Schunk, 2012).

Knowing what motivates and guides (or not) learning, as well as the motivational diversity of students to achieve their academic goals, is relevant in understanding the pattern of behavior in the scholastic environment. Thus, goal orientation explains the reasons students engage (or not) in a task (Pintrich, 2003).

Based on these approaches, several researchers have described two main academic goals; the goal of developing skills, called a mastery or learning goal, and the performance goal, in which students seek to show their skill in relation to others. However, Pintrich (2000) raises the existence of multiple goals, i.e. students may rely on different goals present in an interaction between them at the same time and to varying degrees, generating different motivational profiles and cognitive results.

It should be noted that proposing goals and working with sustained effort to achieve them are different issues. In this sense, volitional strategies play a key role in maintaining intent and motivation in the scholastic environment (Gaeta, Teruel \& Orejudo, 2012). Therefore this research seeks to contribute to the understanding of how high school students generate and use volitional strategies based on their motivational profile.

From the viewpoint of educational psychology, the last 30 years have been important in the study of the motivational processes of students in the scholastic environment. The most recent models suggest goal orientation as an essential aspect to drive students to the achievement of an academic activity. Goal orientation is defined by Pintrich (2003) as the reasons and purposes for task accomplishment.

Although authors prefer certain nuances, literature often focuses its attention on two main goals: learning-oriented goals and performance-oriented goals. However, some authors (Gaeta, Cavazos, Sánchez, Rosário \& Hegemann, 2015) consider both orientations to be more complex, so they expand this differentiation in the way students approach learning and include other goals, such as those of social reinforcement or achievement.

From this approach, the different lines of study on goal orientation have focused mainly on university environments and basic education (Ecos-Espino \& Manrique-Chávez, 2018; Navas-Martínez, Soriano-Llorca, Holgado-Tello \& Jover-Mira, 2016; Rodríguez, Piñeiro, Regueiro, Estévez, Valle \& Núnez, 2018; Ruiz-Esteban, Méndez \& Díaz-Herrero, 2018). However, research regarding goal orientation and the benefits they give in high school is necessary.

There are reasons to consider that students may adopt different combinations of motivational orientations, i.e. they present multiple goals to achieve their academic goals.
Pintrich (2003) suggests that, along with performance and learning goals, there are other reasons that allow students to approach their goals. Therefore, it is considered necessary to take on the combination of learning and performance goals to promote academic achievement. From the multiple goals perspective (Pintrich, 2003), students may be classified according to different motivational approaches, that is, considering the types of goals they are using at a certain time and in a certain context, and resulting in the identification of different motivational profiles.

In addition, depending on the motivational profile, students may use different strategies to regulate their behavior. Based on Zimmerman's theoretical model (Panadero \& Alonso-Tapia, 2014; Schunk, 2012), self-regulation of learning is a control process that people perform regarding their thinking, motivation, actions and emotions, through different strategies to achieve the academic goals that have been established. Within this process, the volitional control allows the student to maintain his or her focus and effort.

During the realization of learning tasks, volition is considered the driving force that allows one to maintain motivation towards the achievement of the proposed goal. As Corno (1993) points out, colloquially volition is thought of as "willpower", and while motivation is necessary to determine and define goals, volition helps maintain effort and persistence to complete the proposed goal.

Volition helps control cognition, motivation and affection, during the realization of the activity. When cognitive control intervenes, it addresses the need to monitor established goals. Motivational control establishes an action plan against distractors or other alternate goals. Emotional control involves maintaining positive emotional states and mitigating negative states that occur during the accomplishment of tasks, as well as negative thoughts, such as the unfavorable consequences of a student who did not achieve the proposed goals (Pintrich, 2000, 2003).

It is important to mention that research efforts have been made that analyze the motivational profiles of students regarding self-efficacy (Ferradás, Freire, Regueiro \& Estéves, 2017; Ferradás, Freire, Regueiro \& Valle, 2018), academic satisfaction (Aguilar-Rivera, 2016; Vergara-Morales, Del Valle, Díaz, Matos \& Pérez, 2019), academic performance (Navas-Martínez et al., 2016) or volitional strategies (Báez-Estradas \& Alonso-Tapia, 2017; Birgili, Seggie \& Kiziltepe, 2019; Estevez, Rodríguez, Valle, Regueiro \& Piñeiro, 2016; McCann \& Turner, 2004), in addition to studies which have considered pedagogical strategies that promote learning strategies, according to students' motivational profiles (Dios-Pérez, 2019; Torrano, Fuentes \& Soria, 2017). However, research that jointly and comprehensively analyzes students' motivational profiles regarding the generation and use of volitional strategies that allow them to stay motivated and persevere when faced with difficulties or alternate goals are still necessary.

The main purpose of this study was to analyze the generation and use of volitional strategies - motivational 
and emotional control - based on the motivational profile of students, and a mixed methodology. Specifically it was specifically sought to (a) identify students' motivational profiles, according to the greatest or least predominance of goals within each profile; (b) identify the distinguishing use of volitional strategies, from students' motivational profile; (c) describe how students generate volitional strategies how they establish them and the reasons and factors that promote them - when faced with distractors and difficulties, based on a greater use of them.

\section{Method}

A mixed method was used to take a more comprehensive look at the object of study and the complementarity of the data. The design was defined as explanatory sequential (Creswell, 2014).

\section{Participants}

The participants were 204 students, between 16 and 17 years of age $(M=16.55 ; D T=0.95)$, enrolled in the fourth semester, of six semesters, of high school, from four schools located in the city of Puebla, Mexico, selected by availability. Of the total students, 74 are women $(36.80 \%)$ and 130 are men $(63.20 \%) ; 134(65.70 \%)$ were from public schools and $70(34.30 \%)$ from private schools.

The selection of the sample in the quantitative phase was incidental non-probabilistic and in the qualitative phase the selection of participants was of typical cases (Creswell, 2014). In the latter phase, 14 interviews were conducted, and with such, the information was complete. The participants interviewed were selected from the following criteria: those who showed satisfactory academic performance and who used more volitional strategies based on the belonging profile (multiple goals profile).

\section{Instruments}

The variables of the study in the quantitative phase were: (1) volitional strategies defined as the thinking and/or behaviors directed at maintaining the intention and achieving a proposed goal despite other distractors or obstacles (Corno, 1993; McCann \& Garcia, 1999; McCann \& Turner, 2004); (2) motivational profiles defined as the reasons and purposes for approaching the achievement of the task, from the combination of different goals (Pintrich, 2003).

The volitional strategies were measured through the Academic Volitional Strategies Inventory (AVSI), proposed by McCann and García (1999) and adapted into Spanish by Gaeta et al. (2015). It consists of 20 items, in a Likert scale from 1 (never) to 5 (always), that measure the use of volitional strategies of control, motivation, and emotion, grouped into: (1) control of self-efficacy; (2) stress reduction; (3) negative incentive. The reliability index (Cronbach Alpha) of the total questionnaire was .818 .
Self-efficacy control includes strategies to regulate and strengthen confidence in the completion of the task, such as remembering past successes or telling oneself "I can do it". Stress reduction encompasses strategies such as counting to 10 to lessen frustration or breathing deeply to reduce anxiety. Negative incentives include thoughts of the potential negative consequences upon not achieving the proposed goals (McCann \& Turner, 2004; Pintrich, 2000).

To analyze motivational profiles, the Achievement Goal Questionnaire proposed by Hayamizu and Weiner (1991) was used and adapted into Spanish by Núñez and GonzálezPienda (1994). It consists of 20 items, on a Likert scale from 1(never) to 5 (always), which evaluate the orientations toward: (1) learning goals, which focus on personal competence and relate to satisfaction and interest in the task; (2) performance targets, which reveal a perspective of comparison with others; (3) social reinforcement goals, which are associated to the need for recognition by teachers, peers and/or family members and (4) the achievement goals, through which one avoids looking incompetent. The reliability index (Cronbach Alpha) of the total questionnaire was .814 .

For the qualitative phase, a semi-structured interview was applied, which was submitted to judging by four international experts. The interview guide consisted of 16 questions, grouped into four dimensions: a) generation of volitional strategies grouped into: environmental control, motivational control, behavioral control and emotional control; (b) reasons for using volitional strategies (internal and external); (c) factors that favor the use of volitional strategies (positive thoughts and feelings); (d) factors that inhibit the use of volitional strategies (negative thoughts and feelings).

\section{Procedure}

Data collection. Quantitative phase instruments (Achievement Goal Questionnaire and AVSI) were applied collectively, during school hours, with teacher approval. The purposes of the study were disclosed in advance, with an average response time of 20 minutes. Students who did not wish to participate left the classroom. In the qualitative phase, the interview with the participants was conducted individually and in an enclosed space to avoid distractors.

Data analysis. To determine the motivational profiles, an exploratory factorial analysis was performed, then a hierarchical cluster analysis and finally a k-means clustering analysis. For the analysis of the differential use of volitional strategies, based on the students' motivational profile, the Kruskal-Wallis test was carried out. Subsequently, the Mann-Whitney-Wilcoxon test allowed analysis on whether there was heterogeneity in the goal orientation groups regarding the use of volitional strategies. Statistical analyses were performed in the SPSS version 22.0 program.

For the semi-structured interview, the quality criteria are established in its application, in elements such as credibility, applicability and auditability, active, reflective listening, heard in the recording of the conversation and 
seen in textual transcripts. A content analysis was carried out to systematically extract, examine, and interpret relevant information (Trujillo, Narango-Toro, LomasTapia \& Merlo-Rosas, 2019).

\section{Ethical considerations}

Prior to conducting the study, the necessary permits were obtained from administrators, teachers and parents, through an informed consent since the participants were minors. Student participation was voluntary, and anonymity and confidentiality of their responses were guaranteed in both phases of the study. Students received no remuneration for their participation. The doctoral research project that gave rise to this work was approved by the University Ethics Committee (July 1st, 2016).

\section{Results}

\section{Students' motivational profiles}

Four motivational profiles were identified consisting of the combination of four types of goals - learning, performance, achievement, and social reinforcement. The first group, called an achievement-oriented motivational profile, was made up of 58 students, who were predominantly achievement goals oriented. The second group, motivational profile with orientation to multiple goals, was made up of 81 students, who showed use of all goals, with a slight elevation in social-type goals. The third group, profile without orientation to goals, had 17 students located in it. Lastly, the motivational profile with performance and learning goal orientation was composed of 48 participants. In Figure 1, the motivational profiles obtained may be seen.

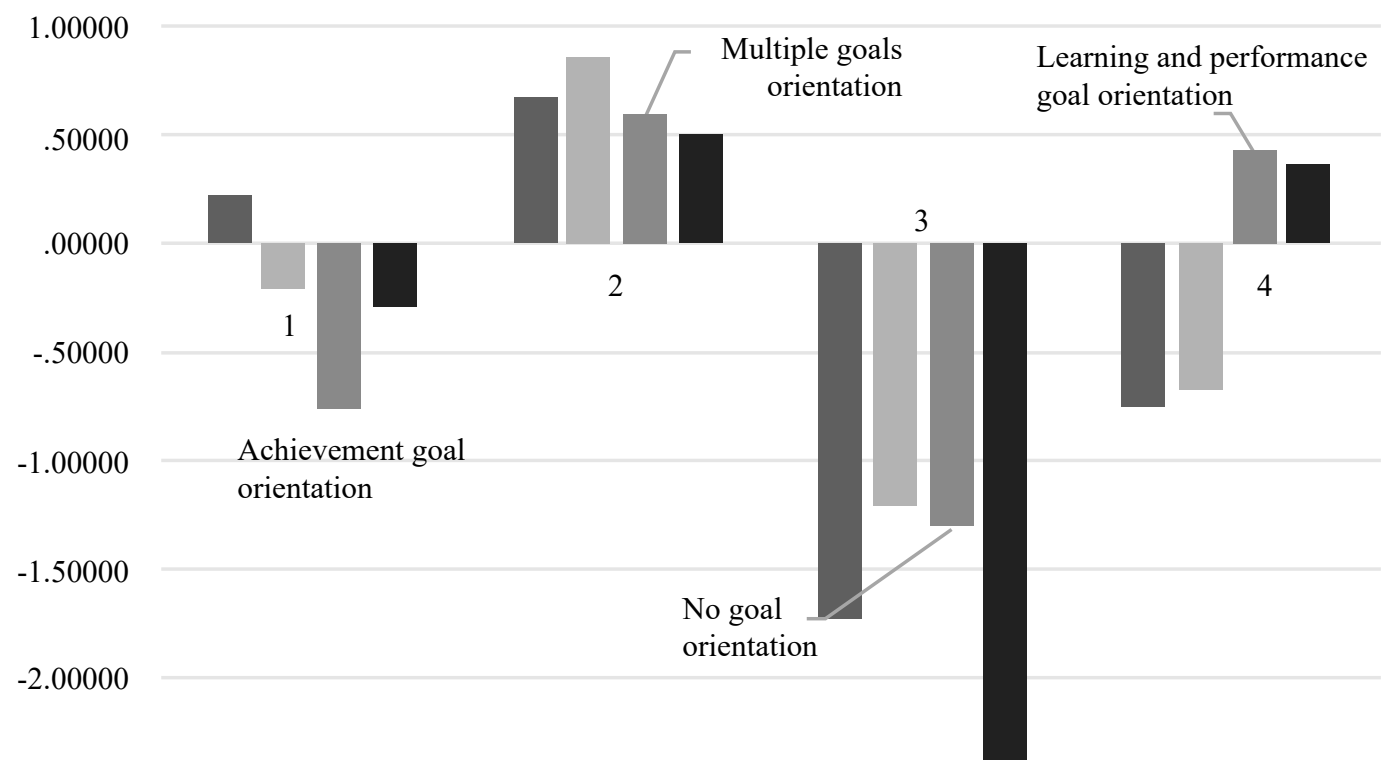

$-2.50000$

$-3.00000$

achievement goals $\square$ Social reinforcement goals $\quad$ Learning goals $\square$ Performance goals

Figure 1. Students' motivational profiles.

Source: Prepared by authors.

\section{Distinguished use of volitional strategies, from students' motivational profile}

The Kruskal-Wallis test allowed the identification of the differential use of students' volitional strategies according to their motivational profile. Regarding selfefficacy control, Table 1 shows that students with a multiple goal orientation profile have the highest value (average range 123.20) and those with a profile not oriented to any of the goals showed the lowest value (average range
68.94). Goal-oriented profiles of achievement (average range 90.51) and performance and learning goal (average range 93.95) showed similar ranges.

Regarding negative incentives, students with a multiple goal-oriented profile had the highest rank (average range 123.73), followed by students with a goal-oriented profile (average range 98.88). Students with a performance and learning oriented profile (average range 79.18) and those who had a profile not oriented toward any goals (average range 79.53) reported similar values. 
In stress reduction, students with multi-goal-oriented profile had the highest value (average range 120.15). Students with an achievement-oriented profile and those with a performance and learning goal orientation profile had an average of 93.47 and 93.21 , respectively. Those with no goal orientation profile had the lowest value (average range 75.44$)$.

Table 1

Average range of volitional strategies regarding the motivational profile

\begin{tabular}{|c|c|c|c|}
\hline $\begin{array}{l}\text { Volitional } \\
\text { strategies }\end{array}$ & Motivational profile & $n$ & $\begin{array}{c}\text { Average } \\
\text { range }\end{array}$ \\
\hline \multirow{5}{*}{ Self-efficiency } & Achievement goals & 58 & 90.51 \\
\hline & Multiple goals & 81 & 123.20 \\
\hline & No goal orientation & 17 & 68.94 \\
\hline & $\begin{array}{l}\text { Learning and } \\
\text { performance goals }\end{array}$ & 48 & 93.95 \\
\hline & Total & 204 & \\
\hline \multirow{5}{*}{$\begin{array}{l}\text { Negative } \\
\text { incentive }\end{array}$} & Achievement goals & 58 & 98.88 \\
\hline & Multiple goals & 81 & 123.73 \\
\hline & No goal orientation & 17 & 79.53 \\
\hline & $\begin{array}{l}\text { Learning and } \\
\text { performance goals }\end{array}$ & 48 & 79.18 \\
\hline & Total & 204 & \\
\hline \multirow{5}{*}{ Stress reduction } & Achievement goals & 58 & 93.47 \\
\hline & Multiple goals & 81 & 120.15 \\
\hline & No goal orientation & 17 & 75.44 \\
\hline & $\begin{array}{l}\text { Learning and } \\
\text { performance goals }\end{array}$ & 48 & 93.21 \\
\hline & Total & 204 & \\
\hline
\end{tabular}

Note. Prepared by authors.
Part of the Mann-Whitney-Wilcoxon test was analyzed as to whether there is heterogeneity in students' motivational profiles in the use of volitional strategies. By comparing students with an achievement goal oriented profile with the multiple goal orientation, a significant difference in the use of the three types of volitional strategies could be seen: self-efficacy control $(z=3.206 ; p<.05)$, negative incentives $(z=2.664 ; p<.05)$ and stress reduction $(z=2.626 ; p<.05)$.

The comparison between the motivational profile with multiple goal orientation and the no goal orientation profile also showed significant differences in the three types of strategies: self-efficacy control $(z=3.079 ; p<.05)$, negative incentives $(z=2.684 ; p<.05)$ and stress reduction $(z=2.632$; $p<.05$ ). Comparing the multiple goal orientation motivational profiles with those with learning and performance orientation, it is noted that there were significant differences in the three types of strategies: self-efficacy control $(z=2.931 ; p<.05)$, negative incentives $(z=3.975 ; p<.05)$ and stress reduction $(z=2.634 ; p<.05)$.

In turn, the association between motivational profiles and volitional strategies did not show significant differences depending on the gender or membership (public/private) of the participants.

\section{Generating volitional strategies that students use}

To find out how students generate the volitional strategies, semi-structured interviews were conducted, considering the main use of these, according to the membership motivational profile; students with multiple goal orientation profile showed greater use of such strategies. Through the analysis of the fourteen interviews, four dimensions and ten categories, based on the codes found during the research, were established, and revised according to the theoretical foundations (McCann \& Turner, 2004; Pintrich, 2000). Table 2 describes the dimensions, categories, and codes. Next, testimonies of each of the dimensions are exemplified.

Table 2

Generation and use of volitional strategies: dimensions, categories, and indicators

\begin{tabular}{|c|c|c|}
\hline Dimensions & Categories & Indicators Examples \\
\hline \multirow[t]{4}{*}{ Generation of volitional strategies } & Control of motivation & Establish goals, self-efficacy \\
\hline & Control of emotion & Actions to reduce stress \\
\hline & Control of behavior & \\
\hline & Control of the environment & \\
\hline \multirow[t]{2}{*}{ Reasons to use volitional strategies } & Internal & Entering college \\
\hline & External & Getting recognition \\
\hline \multirow{2}{*}{$\begin{array}{l}\text { Factors that strengthen the use of the } \\
\text { strategies }\end{array}$} & Positive feelings & Feeling satisfied and happy \\
\hline & Positive thoughts & Remembering a happy event \\
\hline \multirow{2}{*}{$\begin{array}{l}\text { Factors that inhibit the use of the } \\
\text { strategies }\end{array}$} & Negative feelings & Feeling stressed, nervous \\
\hline & Negative thoughts & Feeling afraid, insecure \\
\hline
\end{tabular}

Note. Prepared by authors. 


\section{Generating volitional strategies}

Regarding motivational control, it refers to the use of strategies related to the monitoring, control and regulation of aspects related to motivation itself, such as self-efficacy, attributions, interest, and usefulness of the task, the search for help and negative incentives. From the testimonies it can be seen how relevant it is to students that topics are interesting or helpful for staying motivated, such as the importance they give when asking for help. "I ask for help, if I can't, I go and ask my classmates, my parents, I research a little more and I ask the teacher...", which Fabiola associates with concentration, commenting that when distracted in class she approaches a classmate. In turn, Camila describes her interest in the subject by seeing that she contributes to her learning: “... I like Physics because I learn new things and I feel it is something useful; in Chemistry, I feel the same way as in Physics."

It is further seen that, while an interest in the subject contributes to motivation, setting goals and internal dialogue contribute to its fulfilment. Daniel shows these aspects when commenting:

Yes, there are subjects where I just say no, I don't like them, they don't catch my attention. This past year it was mostly with Ethics, that was one of those things I don't like, these things with Philosophy and that... However, mmm, I set a goal and by the end I had met it.

Emotional control involves stimulating positive moods and emotions that make one feel good, or decrease negative emotions, as well as strategies to reduce stress and maintain effort. As Alexander mentions: “... I just think positive, that everything will go well and that I'm making a good effort." Carlos also puts emotional control into practice when he comments: "... I try to relax because I know we saw everything in class, the teacher gave it to us and that gives me a lot of peace of mind; knowing it is something we already saw makes me not panic." Camila also describes some actions for emotional control. "Well, out of nervousness, I sometimes bite my nails... I start drawing on the desk, I like start to draw something, so that it feels like I'm relating it to something."

Emotional control, in some cases, also involves anxiety to increase effort, which is combined with internal dialogue for self-efficacy control. This is expressed by Karen in describing the confidence she feels in her actions.

I realized that nothing is difficult, that it's all a matter of perception and that... maybe something is a little tougher than something else, but .... Well... to be realistic, difficult things motivate me a little, because I feel like it might make my knowledge grow when I do it.

\section{Reasons to use volitional strategies}

Participants describe among the reasons for using volitive strategies, which allow one to maintain concentration and effort in the study, to be able to have time to perform other tasks or have the recognition of others for their results, and even mentioning the benefits of getting into a good university. As Bernardo mentions: “... When I get good grades feel calm, because it's like I completed something that, well, at the end of the day is going to help me in the day to day and in my future." Eva also sets out the importance of study for her future: “... because I know it's going to help me in my future, in finding a solution, I know I'm going to benefit in my major."

In general, it is seen that the reasons for the use of volitional strategies, motivational and emotional control, may be internal or external and from them different strategies may be mobilized, depending on the situation the student faces.

\section{Factors that strengthen the use of volitional strategies}

The information provided by the participants presents the importance of the environment to promote the students' concentration in the study or the task, in combination with the aspects so as not to give up when faced with difficulties or distracting problems arising during the activity. In several statements, the students show they see the implementation of strategies to strengthen self-efficacy, such as remembering past successes. Francis said, “... When I get good grades, I feel good because, for example, we just had a calculus test and three of us passed with grades of 10 , the others failed. I feel good that I was one of the only ones who got a 10."

Bertha also expresses how good she feels about good grades. "When I get good grades, I'm very proud and satisfied with the work I did." In addition, pride that can generate congratulations from their parents, the teachers, as well as recognition, are other aspects that strengthen the use of volitional strategies, as Alejandro mentions, "My parents congratulate me, but they do not buy me gifts because the best investment is that they support my studies", which is complemented by Enrique's testimony, in which he says, "[it is due to] the support I receive from my parents and my teachers...". Likewise, Bertha, who recalls the positive comments of others, states, "I start to remember what quite a few people have told me, which is motivating, and they have said, 'You can do it; you are very smart."

It is generally noted that parents are an important factor for students to generate volitional strategies; students take into account the congratulations and comments they get for their achievements, but do not receive material incentives. Students also mention teachers as a factor that favors the use of volitional strategies, as well as their good grades.

\section{Factors that inhibit the use of volitional strategies}

The most repeated factor among those inhibiting the use of volitional strategies was a negative environment, particularly distractions that affect concentration or stop one from beginning schoolwork, such as noise, television, social media, among others. Both Gema and Eva express this annoyance by mentioning, “... the noise, the family's voices, the TV, the music that distracts me easily" and "... noise, 
noise distracts me very easily... Also, music, even if it's in the background distracts me and I feel like I need total silence."

Negative thoughts from uncertainty are factors that inhibit students from using volitional strategies, such as not understanding a task, not knowing what's going to happen on an exam, or what will be asked. This could be seen in what Bertha says, “... first I start to feel a little insecure about myself, even though I may have the knowledge, and I start to block my mind, I start to be a little afraid of what I might answer." Amalia also expresses that having a lot of pressure makes her nervous and she does things faster, causing her to make mistakes on the test. In turn, Heidi and Enrique realize the stress caused by trying to understand the subjects and distraction from the lack of interest in the subject, saying"... Philosophy, because it is a lot to understand and understand, I mean, math is understanding, but it's understanding the equation, whereas philosophy tells you this and contradicts you..." and "subjects such as history, administration or biology do not catch my attention and they distract me...".

\section{Discussion}

According to the main objective, analyzing the generation and use of volitional strategies, in accordance with the students' motivational profile, states that motivational profiles are composed of several goals that interact in greater or lesser degree simultaneously. From the evidence obtained, this study contributes to the literature that sets out the relevance of considering the motivational profiles for students' academic achievement, beyond goal orientations independently (Ferradás et al., 2017; Pintrich, 2000). In this study, there are four motivational profiles; the majority of the participants $(n=81)$ showed a multiple goal orientation profile, with a predominance in social reinforcement goals, which highlights the importance of the opinion of others in setting goals of students of this educational level.

In addition, this work contributes to the knowledge of how these different combinations of goals affect the use of volitional strategies. The results show that volitional strategies have a distinguished use according to the motivational profile. The volitional strategies for selfefficacy control were the most commonly used by students with different profiles, except for students with profile with no goal orientation. These findings corroborate those of Estevez et al. (2016), who associate an interest in the task and the search for good work as predictors of self-efficacy.

It emphasizes that the association between motivational profiles and volitional strategies has no significant differences in the gender or membership of the participants, which leads us to delve into these aspects in future research.

On the other hand, in accordance with Gaeta et al. (2012), the generation and use of volitional strategies are accompanied by actions that lead students to the proposed goals, based on different reasons. Among them, the relevance of perceived interest or usefulness in the subjects of the study to persevere in the task, such as the importance they attach to support. Students expressed the need to control anxiety to maintain focus on homework, implying internal dialogue. Among the main reasons for using volitional strategies, it highlights the recognition of others for the good result, which corroborates the importance given to the social aspect. In addition, recognition and support by significant adults, such as teachers and parents, are considered important for students to generate volitional strategies.

Part of our findings is the importance of developing and strengthening the use of volitional strategies in Baccalaureate students which help them sustain effort and concentration during study, as well as cognitive strategies, according to their motivational profile (Bernal, González-Torres \& Naval, 2015). As we have pointed out, both motivation and volition are necessary for students to achieve their academic goals; upon motivating themselves, they can set their goals, but other strategies, work habits, and emotional aspects that allow them to persist until they are fulfilled (volitional strategies) should also be considered.

We express the importance of designing contextualized intervention programs to teach students to acquire and develop these aspects (Torrano et al., 2017), from the students' needs. As we have mentioned, focusing teaching on students' self-regulated learning, using volitional strategies (motivational and affective control), contributes to strengthening commitment and sustained effort to achieve academic goals in students.

It is necessary to mention the limitations of this research, such as dealing with a relatively small sample, from only four schools, which did not allow us to generalize the results to the Mexican high school population. Therefore, future studies must be broadened, through stratified sampling, to include different subjects and schools, as well as other educational contexts of the country.

Another aspect is the transversality of research, which raises the need for longitudinal studies in order to go deeper into variations regarding the use of volitional strategies and the motivational profile of students during their high school studies. Teacher training is also an important aspect that is suggested to be addressed in future research, since an optimal level of knowledge and management of motivational and affective aspects is required carry out teaching effectively.

\section{References}

Aguilar-Rivera, M. C. (2016). Perfil motivacional de un grupo de estudiantes universitarios [Motivational profile of a group of university students]. REXE. Revista de Estudios y Experiencias en Educación, 15(28), 93-106. doi:10.21703/rexe.201628931065

Baez-Estradas, M., \& Alonso-Tapia, J. (2017). Training strategies for self-regulating motivation and volition: Effect on learning. Anales de Psicología, 33(2), 292-300. doi:10.6018/analesps.33.2.229771 
Bernal, A., González-Torres, M. C., \& Naval, C. (2015). La educación del carácter. Perspectivas internacionales [Character education. International perspectives]. Participación Educativa, 4(6), 35-45. Retrieved from https://www.unav.edu/documents/ $8554517 / 10333393 / 2015+$ Ed + Caracter+Perspectiva + edctva.pdf/fb24db6b-9555-40fd-b543-55c934019d5c

Birgili, B., Seggie, F. N. \& Kiziltepe, Z. (2019). Investigating the relationship between volitional strategies and academic achievement in a flipped learning environment. Croation Journal of Education: Hrvatski Casopis Za Odgoj I Obrazovanje, 21(1), 345-375. doi:10.15516/cje.v21i1.3006

Corno, L. (1993). The best laid plans: Modern conceptions of volition and educational research. Educational Research, 22(2), 14-22. doi:10.3102/0013189X022002014

Creswell, J. (2014). Research design: Qualitative, quantitative and mixed methods (4th ed). Los Angeles, CA: Sage.

Dios-Pérez, M. J. (2019). Perfiles de estudiantes universitarios y su ajuste a las metodologías de enseñanza [Profiles of university students and their adjustment to teaching methodologies]. International Journal of Developmental and Educational Psychology, 1(1), 171-182. doi:10.17060/ijodaep.2019.n1.v1.1404

Ecos-Espino, A., \& Manrique-Chávez, Z. (2018). Metas académicas y rendimiento académico en estudiantes universitarios de la ciudad de Abancay [Academic goals and academic performance in university students of the city of Abancay]. Apuntes de Ciencia \& Sociedad, 8(1), 33-39. doi:10.18259/acs.2018004

Estevez, I., Rodríguez, S., Valle, A., Regueiro, B., \& Piñeiro, I. (2016). Incidencia de las metas académicas del alumnado de secundaria en su gestión motivacional [Incidence of academic targets of secondary school pupils in their motivational management]. Aula Abierta, 44(2), 83-90. doi:10.1016/j.aula.2016.03.001

Ferradás, M. M., Freire, C., Regueiro, B., \& Estévez, I. (2017). Perfiles de múltiples metas y autoestima en estudiantes universitarios [Multiple goal profiles and self-esteem in university students]. Revista de Estudios e Investigación en Psicología y Educación, (1), 77-81. doi:10.17979/reipe.2017.0.01.2256

Ferradás, M., Freire, R., Regueiro, B., \& Valle, A. (2018). Defensive pessimism, self-esteem and achievement goals: A person-centered approach. Psicothema, 30(1), 53-58. doi:10.7334/psicothema2017.199

Gaeta, M. L., Teruel M. P., \& Orejudo, S. (2012). Aspectos motivacionales, volitivos y metacognitivos del aprendizaje autorregulado [Motivational, volitional and metacognitive aspects of self-regulated learning]. Electronic Journal of Research in Educational Psychology, 10(1), 073-094. Retrieved from http://ojs.ual.es/ ojs/index.php/EJREP/article/view/1485/1772
Gaeta, M. L., Cavazos, J., Sánchez, A. P., Rosário, P., \& Högemann, J. (2015). Propiedades psicométricas de la versión mexicana del Cuestionario para la Evaluación de Metas Académicas (CEMA) [Psychometric properties of the Mexican version of the Academic Goals Questionnaire]. Revista Latinoamericana de Psicología, 47(1), 16-24. doi:10.1016/S0120-0534(15)30002-9

Hayamizu, T., \& Weiner, B. (1991). A test of Dweck's model of achievement goals as related to perceptions of ability. The Journal of Experimental Education, 59(3), 226-234. doi:10.1080/00220973.1991.10806562

McCann, E. J., \& García, T. (1999). Maintaining motivation and regulating emotion: Measuring individual differences in academic volitional strategies. Learning and Individual Differences, 11(3), 259-279. doi:10.1016/ S1041-6080(99)80003-X

McCann, E. J., \& Turner, J. E. (2004). Increasing student learning through volitional control teachers college record. Teachers College Record, 106(9), 1695-1714. Retrieved from http://www.sfu.ca/ jcnesbit/EDUC220/ ThinkPaper/MccannTurner2004.pdf

Navas-Martínez, L., Soriano-Llorca, J. A., Holgado-Tello, F. P., \& Jover-Mira, I. (2016). Las metas múltiples: Análisis predictivo del rendimiento académico en estudiantes chilenos [Multiple goals: Predictive analysis of academic performance in Chilean students]. Educación XXI, 19(1), 267-285. doi:10.5944/educxx1.14225

Núñez, J. C., \& González-Pienda, J. A. (1994). Determinantes del rendimiento académico [Determinants of academic performance]. Oviedo, España: Universidad de Oviedo.

Panadero, E., \& Alonso-Tapia, J. (2014). How do students self-regulate? Review of Zimmerman's cyclical model of self-regulated learning. Annals of Psychology, 30(2), 450-462. doi:10.6018/analesps.30.2.167221

Pintrich, P. R. (2000). Multiple goals, multiple pathways: The role of goal orientation learning and achievement. Journal of Educational Psychology, 92(3), 544-555. doi:10.1037/0022-0663.92.3.544

Pintrich, P. R. (2003). A motivational science perspective on the role of student motivation in learning and teaching context. Journal of Educational Psychology, 95(4), 667-686. doi:10.1037/0022-0663.95.4.667

Rodríguez, S., Piñeiro, I., Regueiro, B., Estévez, I., Valle, A., \& Núñez, J. C. (2018). Bienestar emocional de los estudiantes universitarios: El papel de la orientación a metas y las percepciones de control [Emotional wellbeing of University Students: The role of goal orientation and control perceptions]. Publicaciones 48(1), 173-181. doi:10.30827/publicaciones.v48i1.7324

Ruiz-Esteban, C., Méndez, I., \& Díaz-Herrero, A. (2018). Evolución de las metas académicas en función del sexo y la edad y su influencia en el rendimiento académico en adolescentes murcianos [Evolution of academic goals based on gender and age and their influence on academic achievement in adolescents in Murcia]. Educatio Siglo XXI, 36(3), 319-332. doi:10.6018/j/350021 
Schunk, D. H. (2012). Teorías del aprendizaje: Una perspectiva educativa [Learning theories: An educational perspective] (L. E. Pineda Ayala \& M. E. Ortiz Salinas, Trans.). Ciudad de México, México: Pearson.

Torrano, F., Fuentes, J. L., \& Soria, M. (2017). Aprendizaje autorregulado: Estado de la cuestión y retos psicopedagógicos [Self-regulated learning: State of the issue and psycho-pedagogical challenges]. Perfiles Educativos, 39(156), 160-173. Retrieved from: http:// www.scielo.org.mx/scielo.php?script $=$ sci_arttext\&pid= S0185-26982017000200160\&lng=es\&tlng $=$ es

Trujillo, C. A., Naranjo-Toro, M. E., Lomas-Tapia, K. R., \& Merlo-Rosas, M. R. (2019). Investigación cualitativa [Qualitative research]. Ibarra, Ecuador: Editorial Universidad Técnica del Norte UTN.

Vergara-Morales, J., Del Valle, M., Díaz, A., Matos, L., \& Pérez, M. V. (2019) Perfiles motivacionales relacionados con la satisfacción académica de estudiantes universitarios [Motival profiles related to the academic satisfaction of university studentes]. Annals of Psychology, 35(3), 464471. doi:10.6018/analesps.35.3.320441

Maria del Socorro Rodríguez-Guardado is a Professor of the Universidad Popular Autónoma del Estado de Puebla, Puebla-México.

Martha Leticia Gaeta is a Professor of the Universidad Popular Autónoma del Estado de Puebla, Puebla-México.

\section{Authors' Contribution:}

All authors made substantial contributions to the conception and design of this study, to data analysis and interpretation, and to the manuscript revision and approval of the final version. All the authors assume public responsibility for content of the manuscript.

Associate Editor:

Vanessa Barbosa Romera Leme

Received: Jan. 23, 2020

1st Revision: Jul. 27, 2020

2nd Revision: Oct. 16, 2020

3rd Revision: Nov. 12, 2020

Approved: Nov. 20, 2020
How to cite this article:

Rodríguez-Guardado, M. S., \& Gaeta, M. L. (2021). Motivational profiles in high school students: Generation and use of volitional strategies. Paidéia (Ribeirão Preto), 31, e3118. doi:https://doi.org/10.1590/1982-4327e3118 